\title{
Islam and Economic Development: Exploring the Role of Indonesian Muslim Society in Developing Islamic Microfinance Institution
}

\author{
Ayi Yunus Rusyana ${ }^{1}$ \\ ${ }^{1}$ Faculty of Sharia and Law, Sunan Gunung Djati State Islamic University, Bandung Indonesia
}

Email: ayiyunus@gmail.com

\begin{abstract}
Although a religion is considered as a one of the cultural barriers that can impede an economic development, nevertheless in this paper I prove that Islam as well as Muslim society has a big role to empower economic life in Indonesian Muslim. The growth of Bayt al-Māl wa al-Tamwīl (BMT), Islamic microfinance institution, initiated by Muslim community is a great evidence on how religioun gave a positive impact in economic development in Indonesia. Using the theory of collective action proposed by Alberto Melucci, I explore the main factors that influenced Muslims to establish BMT, and how BMT movement develops in Indonesian Muslim society. Overall, in this paper I argue that the BMT movement can be considered as a social movement where the civil society takes more important role than the state. Interestingly, the lack of regulation is not becoming an obstacle for Muslim society to establish and develop BMT in some regions in Indonesia.
\end{abstract}

Keywords: Bayt al-Māl wa al-Tamwīl (BMT), Muslim society, social movement

\section{A. INTRODUCTION}

Although in the Annual Speech of 2010 the President of Indonesia, Susilo Bambang Yudhoyono (SBY), said that the number of poor people (the population with expenditure per capita per month below the poverty line) in 2010 decreased by 1.51 million compared with March 2009 which amounted to 32.53 million persons, poverty, in my opinion, is still a crucial problem in Indonesia. The report of Central Statistics Agency (BPS) Indonesia quoted by SBY explains that the standard poverty line set by the BPS is IDR 182.636 (about US $\$ 20$ ) or IDR 6.000 (about US\$ 0.6) per day. The number is of course very small and, therefore, is considered illogical according to the rising of prices of essential goods (rice, oil, and another food) linked to increased fuel prices.

The state is actually the prime stakeholder who has responsibility to eradicate the poverty among its citizens. The Constitution of 1945, particularly in Act 34, clearly describes that the State is responsible for ensuring that its citizens live in prosperity. According to Sachs,( Jeffrey D. Sachs, 2005), the state actually has many roles to play in economic development such as financing highpriority infrastructure projects, creating an environment conducive to investments by private businesses, exercising self-restraint in demanding bribes or side payments, maintaining internal peace and safety, and maintaining judicial systems. When the governments are unable to perform their most basic functions, they fail to achieve economic growth. In addition, Sachs discusses physical geography, the lack of innovation and cultural barriers as other factors causing the failures of countries in order to achieve economic growth.

From these factors, I am interested to highlight "the cultural barriers", because Sachs considers religious norms as the cultural barriers that become the obstacle of economic development. For 
some countries, perhaps religion becomes the problem in reducing the poverty. However, in Indonesia, we can see the growth of Islamic economic institutions, such as Bayt al-Māl wa alTamwīl (BMT), initiated by Muslims in effort to empowering economic civil society. It is usually established by individual or group initiatives to help micro-entrepreneurs as a strategy for eradicating rural poverty, especially in villages or traditional markets, operationally based on Shari'ah principles and cooperation. BMTs did expansed rapidly after 1996, as a result of promotion by Pusat Inkubasi Bisnis dan Usaha Kecil/PINBUK (Center for Micro Enterprise Incubation), a non-government organization, and continued throughout the financial crisis.

Discussing BMT movement in Indonesia is very interesting, because this institution is initiated by Muslim civil society based on Islamic teaching. In other words, through this institution, Muslim civil society takes an important role to solve the problem, which the state must be responsible to do. Furthermore.

\section{B. METHODOLOGY}

This research will examine Sachs's thesis, stating that religious norms will be obstacles in economic development. Hence, will examine how BMTs play a role in strengthening Muslim economy with answering the following two questions: "What are the main factors influence Muslims to establish BMT?" and "How does BMT movement develop in Indonesian Muslim society?"

\section{RESULT AND DISCUSSION}

\section{Literature Review: The Development of BMT in Indonesia}

BMT (Bayt al-Māl wa al-Tamwīl) is the microfinance institution known as Islamic savings and loan cooperative initiated by Indonesian civil society. Its movement is actually begun by Salman Mosque activists in ITB/Insititut Teknologi Bandung, in 1980s. They created Teknosa, Islamic Microfinance Cooperative that growth rapidly. Unfortunately, it is finally bankrupt. The first real BMT, then, emerged in Jakarta in 1992 namely BMT Insan Kamil pioneered by Zainal Muttaqin, Aries Mufti and Istar Abadi. Soon after its founding, some people, particularly in Java area, founded the same institution. Most of them come from well educated Mosque activists, Islamic Organisation such as Muhammadiyah, and community leaders.

The accurate data about BMT is actually not provided yet, however, Aries Muftie, the leader of Asosiasi BMT Seluruh Indonesia (Absindo), said that there are about 3000-4000 BMTs in Indonesia. Furthermore, Saat Suharto,( http://www.republika.co.id), CEO of BMT Venture Capital, said that BMT in 2010, grew on average between 35 and 40 percent and will continue in 2011.

Although having a potency to strengthen Muslim economy, there have been very few social studies on BMT. Lesmana (http://www.republika.co.id), did research about the role of BMTs in three provinces in Indonesia, namely West Java, Central Java and South Sulawesi. In this paper, he presented the main empirical findings as follows. Firstly, some of observed BMTs have a high performance in terms of asset growth. Secondly, BMT activities have a positive socio-economic impact on micro enterprises which become its client. Thirdly, the prospect of BMTs are promising either Shari'ah based on microfinance or as an empowering agent for micro enterprises in the real sector.

What Lesmana said about the performance of BMTs is very interesting. However he did not explain what main factors do influence their performance. Hence, the research about BMT 
conducted by Adnan and his associates is needed to present in this paper, because they evaluate and analyze the main factors influencing a high performance of BMTs. According to them, the salary rate of management, the education and the management skill of personnel involved in daily operation and the product attributes are the main factors beyond the high performance of BMTs. (Tedy Lesmana, 2008).

Concerning the BMT's performance and its development in Indonesia, Sakai (Minako Sakai, 2008), was interested to examine the perceptions of those who are directly involved in providing or obtaining Islamic microfinance. He also described how BMTs operate including their legal and financial structure, the service they provide, and their internal management structure. He also explored that the founder, users and employees have high motivations and aspirations to operate BMTs.

In addition, Kholis completed the previous research when he examined the contribution of BMT in increasing social welfare particularly in Indonesia. According to the experience of BMT Dana Shari'ah in Yogyakarta, his research shows that BMT achieves positive results of Islamic micro finance activities. The financing activities done by BMT Dana Shari'ah generate positive economic effects including income growth and reducing poverty, self employment, asset ownership, food security, and the capability to make their children educated.( Nur Kholis, 2009)

Although all of previous authors demonstrate the development of BMTs and their role in Islamic finance system in Indonesia, there is no explanation about BMT movement. In my opinion, the researchers seem to consider BMT as merely an institution without connecting with the state and civil society. They do not realize that such an institution is not established in an empty space. For instance, Kholis (2009) presented the achievement of BMT Dana Shari'ah in Pakem Yogyakarta in reducing poverty. Unfortunately, he did not examine how and why the BMT obtain some achievements in empowering civil society, and what is the role of religion, civil society and the state to support this institution.

\section{The Collective Action: Theoritical Framework}

According to Pepinsky, a national financial system is usually not independent from political influence. Quoting Krishner, he argues that political considerations lie at the heart of modern finance from monetary policy goals to the choice of monetary institutions. Therefore, Islamic financial systems do not emerge spontaneously either because the national financial systems do not arise absent a state to create them (Thomas B. Pepinsky, 2012).

The spread of Islamic finance to Indonesia was also shaped by political influence. The first Islamic financial institutions arrived somewhat later in Indonesia than they did in other Muslim-majority countries, for under the New Order Islamic finance, like any other conspicuously Islamic behavior, was linked to radicalism and extremism (Angelo M. Venardo, 2006). As a consequence, advocates for Islamic finance suffered from the same obstacles that the country's popular Muslim organizations faced under Soeharto's rule. Only in the early 1990s, when Soeharto began to adopt a more conciliatory stance vis-à-vis Islamists were Islamic financial institutions permitted to organize (Robert, W. Hefner, 2003).

Relating to this study, I will say that the BMT movement can be considered as a social movement where the civil society takes more important role than the state. Therefore I will use the theory of collective action proposed by Melucci (Alberto Melucci, 1996) which provide a meaningful basis for analysis of social movements. He proposes the concept of instrumental movement and expressive 
movement. Concerning the organization's objectives, he distinguish analytically, between the two concept. According to him, expressive movement goals are oriented towards the satisfaction of the social and psychological needs of the movement's members through participation and solidarity; the latter, instrumental movement goals, are achieved in the attainment of specific goods external to the organization. This distinction may be useful in operational terms, but should be applied with some caution to contemporary forms of action.

\section{A Historical Background of BMT Establishment}

The term Bayt al-Māl wa al-Tamwīl, according to Antonio ( See Muhammad Syafii Antonio, 2008), is taken from the Bayt al-Mâl, one institution at the time of Prophet Muhammad which is responsible for national budgeting, maintaining the stability of the money supply, and handling domestic and international payments. This institution had developed under the second caliph, Umar Ibn Khattab (ruled 634-644 CE), and had some branches set up in every capital city of the caliphate to collect taxes and administrative fees, manage the spoils of war and raise charitable funds. In addition, they were also used to finance infrastructure and pay wages of states officers.

The BMT is the combination of the Bayt al- al- Māl activities and wa al- Tamwīl. According to this combination, BMT has conceptually two functions: first, Bayt al- Māl (Bayt= house, Māl = Wealth) is accumulating zakah, infaq and sadaqah for qard hasan (benevolent credit) scheme and other social welfare activities; second, Bayt al-Tamwil (Bait= house, Tamwill= developing the wealth) is accumulating saving from the community and furnishing various scheme of investment loan and working capitals based on Shari'ah principles to the petty businessmen (M. Amin Aziz, 2008).

The idea of BMT establishment should be related with the tendency of Indonesian Muslims to have their own bank applying Islamic economic system. In the 1970s, they proposed a planning to establish Islamic bank. However, this idea was initially suspected of being part of the remnants of the Islamic State ideas, so it was rejected by the government. The official reason that they put forward, according to Dawam Rahardjo (M. Dawam Rahardjo, 2002), is that Islamic bank smashed with the banking legislation which did not provide space for the operation of the bank without interest.

In the mid-1980s, MUI began discussing the possibility of establishing an Islamic bank. Although it has long been regarded by the critics of the government as a corporate mechanism to co-opt the clergy, MUI actually had always internal diversity. Therefore, in line with the increasing thinness of the government against Islamic religious concerns, and also in line with the more apparently results from the rise of Islam, some scholars in the MUI began reviewing the possibility to apply for re-plan the establishment of an Islamic bank (Robert, W. Hefner, 2003).

Furthermore, on August 19 to 20, 1990, MUI hosted a workshop held in Cisarua, Bogor. Although the legal status of interest was not decided yet in the workshop, some participants did agree to establish an interest-free bank based on Islamic law. Recommendations from the workshop was followed up by assigning MUI Leadership Council to initiate the establishment of the bank and eventually formed the MUI banking team led by M. Amin Aziz and supported by ICMI's legal team headed by Karnaen Perwaatmaja (Darul Aqsha, et.al, 1995). Finally Bank Muamalat Indonesia (BMI), the first Islamic Bank, was founded in 1991, after Soeharto gave permission and supported it.

The establishment of BMI, then, was considered by Effendi (Bachtiar Effendi, 2003), as a one of four political accomodation types to Islam: structural accommodation, legislative accommodation, infrastructural accommodation, and cultural accommodation. Structural accommodation is 
recruiting some Muslim leaders in executive agencies (bureaucracy) and legislative institutions of the state. This kind of accommodation is clearly seen when President Suharto supported the establishment of ICMI (Association of Indonesian Muslim Intellectuals) in 1990. The legislative accommodation associated with the issuance of laws or some regulations associated with Islam as an independent and legitimate rule. In addition, the policy of accommodation are ratification of the National Education Act of 1989, enacting laws religious courts, the permissibility of wearing the hijab in 1991 and legislation relating to Islamic banking in Indonesia in 1992. The infrastructural accommodation is the provision of infrastructure required Muslims to perform their religious obligations. One form of this accommodation is the willingness of the government not only to allowed, but also to helped the establishing of Bank Muamalat Indonesia (BMI) in 1992.

Why Indonesian Muslims has a strong tendency to establish Islamic bank can be explained by some factors; firstly, they have a theology emphasizing that Islam is a total way of life. In this sense, they believe that Islam is a comprehensive religion providing a solution to all problems of life. Thus Islam has to be accepted in its entity and to be applied to the family, to the economy and to the politics (Ibid). The holistic view of Islam, according to Saeed (Abdullah Saeed, Riba, 1996), was influenced by Neo-Revivalism, a great movement in the first half of the 20th century coming from Egypt (Ikhwān al-Musliminn founded by Hasan al-Banna) and Indian (Jamaat-i Islami founded by Abu Ala al-Mawdudi). Neo-revivalism, according to him, was in part a continuation of the revivalism, and a reaction to the excesses of secularism in the Muslim world. It focused on the following important issues: resistance to the 'Westernization' of the Muslim community (ummah); advocacy of the self-sufficiency of Islam and of Islam as a way of life; and rejection of any interpretation of the Quran or Sunnah. He points out that neo-Revivalist movements appeared both in Egypt, marked by the Muslim Brotherhood (Ikhwān al-Musliminn), which was founded by Hasan al-Banna (d 1949), and in the Indian subcontinent, marked by the Jamaat-i Islami (Islamic Party), which was founded by the Pakistani Scholar Abu Ala Mawdudi (d 1979).

The neo-Revivalists believed that Islam had answers for all the modern-day ills of both the East and the West. According to them, Muslims should implement Islamic beliefs, values and law, and they then could re-establish themselves as they had been in the past and could once again become contributors to world civilization, reversing the course of humiliation they had undergone during the colonialism and imperialism from the West. Based on this view, the neo-Revivalists emphasized that the implementation of criminal and family laws must refer to Qur'an and Sunnah. In addition, they identified interest on loans as riba (usury), thus Muslims should implement an economic system based on Islamic principles. To sum up briefly, we can say that the neoRevivalist theology was more influential to the Indonesian Muslims in the establishment of an Islamic bank than the Modernist one.

Secondly, the idea to establish an Islamic bank using a profit and lose sharing system is started from an opinion that interest is riba because it contains extra payment (ziyādah). Therefore interest, according to them, is harām (prohibited). Consequently, many Muslims refuse to deal with conventional banks and prefer to keep their money "under the bed". In the New Order era that emphasizes economic growth, the ability of public competition in terms of capital accumulation can not be separated from the role of banking institutions. This opinion, then, gave a great influence to some Muslims to have Islamic bank that free from interest.

Thirdly, the Chinese dominance in the economics field, on the one side, and the poverty of Muslims, on the other side, become a strong background on why Indonesian Muslims intend to establish an Islamic bank. The gap between Muslims and Chinese in the control of the economy is very clear. Hefner (Robert, W. Hefner, 2000), reported that in the mid-1980s, an estimated 70-75 
percent of domestic private capital is owned by Chinese. The concentration of ethnic is getting a great view of the fact that as a group, Chinese is only 3-4 percent of Indonesia's population, while Muslims at that time amounted to around 88 percent.

The hegemony of Chinese businesses simply could not be removed from the New Order government's policy to conduct economic collaboration with them. Their business community had become a partner in national development and they obtained the capital, skills, entrepreneurs, and access to financial networks in East and Southeast Asia (Richard Robison, 1986). In the 1970s, 80 percent of the total allocation of state credits was granted to the Chinese. In return for agreements, certain elite among the business leaders gave their indigenous partners compensation in the form of direct payments, stock blank or joint business (lbid). For Muslims, such treatment was a form of injustice that resulted in economic inequality that led to the creation of jealousy, which later crystallized into an attitude of "anti-China". These imbalances lead to stratification in the field of revenue. Ethnic Chinese views of economic status are at higher levels than native citizens.

The two Government policies, supporting the Chinese businessmen and marginalizing Pribumi, are what led to the Muslim reaction to propose the application of Shari'ah into the strict application of the economic sector. Although, according to Hefner (Robert, W. Hefner, 2000), it is not the only shown reaction, because some Muslims were involved in a strong polemic of "anti-China", and the others tried to did business with Chinese. Some people claim that there is no Islamic economy and Muslims must learn modern management techniques. However, in the 1990s, when Indonesia began to enter a competitive stage of economic development, Indonesian Muslims began to wonder about what was actually needed to ensure that they would also be able to enjoy the fruits of development. Finally, they took the initiative to establish Bank Muamalat Indonesia (BMI), as part of their effort to strengthen the participation of Muslims in national economic development.

For Muslims, according to Hefner (Robert, W. Hefner, 2000), the establishment of BMI is an important innovation having the potential of bringing marginalized people from conventional banking to a modern economy. Thus, Islamic banking can help to strengthen the small Muslim middle class and to empower Muslim economic interest. Furthermore, some supporters of BMI claimed that this bank will not require its clients to have collateral to get bank capital. Freed from collateral requirements, Islamic banks would be better able to service small, capital-poor entrepreneurs.

In fact, Islamic bank could not service small entrepreneurs or poor people who intend to start a business. They are usually difficult to obtain capital financing agreement from Islamic Bank because they could not fulfill the requirements, such as giving collateral or having at least two years business experience. Therefore, some Islamic NGO activists created the BMT concept, as described above, to fill a gap left by the Islamic bank, which have largely neglected the needs of the working poor. Sakai (Minako Sakai, 2008), states that Amin Aziz, a pioneer figure in the BMT movement and the establishment of Bank Muamalat Indonesia, "found that the bank was severally constrained by the need to produce profit for shareholder, and in practice catered only to people who were already financially well established".

\section{BMT as a Social and Economic Movements}

Since its establishment, BMT is designed as an Islamic finance institution which is focused on the small entrepreneurs or poor people. It attempts to assist the development of micro and business ketch, especially capital aid. To help launch the business capital, BMT tries to raise funds, 
particularly from local communities in the vicinity. In other words, this institution attempts to organize efforts to help each other inter-residents of an area (community) in economic problems. Most of BMTs were established in the form of cooperative because it has been widely recognized by society and it is considered as the form which can give a formal legal status. However, according to Aziz (Amin Aziz, 2007), there are some BMTs created in the informal community organizations or associations of local communities. In general, both a form and a legal basis of BMT were not considered as the important factor at the beginning of its establishment. When its activities began to grow, then, the need to fix its organisation, including legality aspect, emerge in the minds of the founders and managers. Almost all of BMT's activists choose the cooperative as a legal entity or at least it is used as its concept. Furthermore, the phenomenon of the establishment and development of BMT were not only limited by economic considerations, but also by the desire to implement Islamic values, in accordance with the mention of self-Islamic connotation. In short, there is relation between BMT and Islam as a doctrine for Muslim economic life.

In addition, most BMTs were born and developed by Islamic community, like jamā'ah (member) of mosque, pilgrims community, pesantren (Islamic Boarding Schools), or Islamic community organizations. BMT Daarut Tauhid (DT) is one example of this institution which was founded by follower of jamā'ah pengajian in Geger Kalong-Bandung, West Java. In the beginning, as reported by Aziz (Amin Aziz, 2007), Abdullah Gymnastiar, the founder of Pesantren Daarut Tawhid known as Aa Gym, convey ideas to his santris (students) to establish Islamic economy institution. The idea was welcomed by his santri by establishing BMT DT on July 14, 1994, with initial capital IDR 250,000. (http://www.kopontrendt.com). Although started with the small capital, they eager to operate it after getting a skill training from PINBUK. In addition, the establishment of BMT is motivated by a sense of high concern to the practice of moneylenders (usurer) who has trapped the weak economy. At the time, many poor people were caught by them because they have no other choice. They could not access Islamic bank to borrow some money because its amount is very small (about IDR 100,000-1.000.000), and they can not provide collateral that asked by bank staff. Finally, they borrow money from moneylenders even they have to pay very high interest rate. BMT DT was subsequently established as an alternative for them to borrow money with more easy refund.

Members of Majelis Taklim gave a positive response to the BMT. In the first year, there were at least 100 people who entrust their money in this institution. Starting with their money, BMT DT has been developing some business institutions, such as mini market, cafe, cottages, or shops. Until 2006, this institution assets are amounted to IDR 10,9 billion with the number of savers are 5000 people and the amount of busnisess funded by BMT are 800 small entrepreneurs. One of important factors that led to the development of BMT is the figure of Aa Gym. Many people entrust their money because they believe in Aa Gym as well as believe that entrust their money in this institution will help pesantren in spreading the teachings of Islam because its benefits BMT will support the Da'wah program's Daarut Tauhid. However, BMT DT businesses, according to Hoesterey, are declines in 2007, after Aa Gym did marry with his second wife (polygamy). Most of his female followers boycott his BMT's products (James B. Hoesterey, 2008).

Another Islamic Microfinance Cooperative was established by Muhammadiyah, the biggest modern Muslim organizations. However, in contrast with BMT that already exist, they use the name of Baitul Tamwil Muhammadiyah (BTM). The organization chooses it, because Muhammadiyah already has Lembaga Amil Zakat Muhammadiyah (Lazismuh) which serves as Baitul Mal. In the National Seminar and Workshop on "Revitalization of the Muhammadiyah Movement for Economic and Community Empowerment" in Yogyakarta on February $7^{\text {th }}, 2010$, 
Su'ud, BTM Wiradesa Manager, explained: "Currently in Muhammadiyah, [BMT] was distinguished to both Baitul Maal and Baitul Tamwil, because in our opinion, Maal and Tamwil should be separated" (http://pdm1912.wordpress.com).

BTM Wiradesa is one of the most successful of the Muhammadiyah Islamic Microfinance. According to Su'ud, this institution was established with initial capital of IDR 25 million coming from grants (hibah). Based on the grantor's message, all of the funds channeled to the empowerment the poor through loan facilities Virtue (Qord al-Hasan). Loan recipient is only obligated to return the loan principal, and if able they are advised to give infaq. To make more independently develop, BMT's management argues that it conduct business development. In addition to managing the grant funds, BTM Wiradesa was then directed to institute a mediator that facilitates the interests of the community who have excess funds (agniyā /the rich people) to those who lack or need of funds (masakin/the poor people). By becoming a mediator institution, the existence of BTM Wiradesa expected to provide benefits to society because it may play a role in community empowerment activities (http://pusatbtm.wordpress.com).

Another interesting phenomenon to observe is that even BMT was burdened by a variety of ideals or normative values, such as for social empowerment of the poor, BMT can be professionally managed and push to make a profit. In Yogyakarta, BMT Beringharjo is an established institution that serves the needs of micro-financing urban traders in the market including Beringharjo. This institution has been operating since 1994 and in 2003 its assets had reached IDR 23 billion, -. It continues to help SMEs through Baitul Tamwil (its business), while the Baitul Maal (treasurer), his offer various empowerment programs. Since 2006, BMT Beringharjo has been offering not only savings services, but also investment schemes, which is primarily intended for overseas workers (Tenaga Kerja Indonesia/TKI) in Hong Kong through Beringharjo Investasi Sharia (BISA). Through this scheme, the workers, which are mainly consisting of the female domestic helpers from East Java, become investment partners and establish a new BMT in their villages. The scheme will result in the establishment of new branches in Ponorogo, Madiun, and Kediri in 2008.

Despite being profitable financial institutions, some of BMTs have also been successfully helping small entrepreneurs to develop their business and reduce poverty. According to the experience of BMT Dana Shari'ah in Yogyakarta, BMT achieves positive results of Islamic micro finance activities. The financing activities done by BMT Dana Shari'ah generate positive economic effects including income growth and reducing poverty, self employment, asset ownership, food security, and the capability to make their children educated (Nur Kholis, 2009).

The facts or phenomena of growth and development of BMT show us a BMT movement in Indonesia. The word "movement" is mentioned to emphasize the idealistic aspects of BMT's activists who want to alleviate poverty based on Islamic values. It is also showing the respect and appreciation for its activists, that is, those who pioneered, manage and develop the BMT. They are generally willing to sacrifice both material and labor, at least willing to reward work which is relatively lower than if they work somewhere else. Whereas most of them have adequate personal capabilities, which if desired, they are very possible to work elsewhere in exchange for a much better salary.

Another advantage of BMT movement is the formation of a solid community, which is not only bound by economic interests, but also bound by the values of brotherhood and commitment to Islamic law. Hospitality forums and lectures become a means of gathering a lot of dimension, but they are positive aspects. So the dimensions of economic, sociological and religious aspect were united within BMT movement. Therefore, Sakai and Marijan identified the BMT as a "social 
entrepreneurship" that is part of the field of science emerging entrepreneurship. This concept can be defined as a process that involves the use and integration of resources in an innovative way to opening opportunities to accelerate social change and/or meet social needs. The main characteristic of social enterprises is driven by the awareness to achieve the objectives and social values, not only to maximize personal benefit" (Minako Sakai and Kacung Marijan, 2008).

\section{BMT and the Problem of Regulation}

One of the problems still faced by BMT is the lack of regulation governing the existence and development of BMT as an institute of Islamic microfinance. In fact, this institution has grown rapidly both in urban and rural areas. Until now, there is draft Bill (RUU/Rancangan UndangUndang) of Lembaga Keuangan Mikro (Micro Finance Institution) No. XXX of 2007 in the House of Representatives (DPR), unfortunately it is not seriously discussed yet. Meanwhile, the government still uses the State Minister of Cooperatives and Small and Medium Enterprises No. 91/Kep/M.KUKM/IX/2004 on Guidelines for Implementation of Cooperative Activities Financial Services Shari'ah (KJKS/Koperasi Jasa Keuangan Shari'ah), in addition subject to the Act Cooperative No. 25 of 1992 and Law No. 9 of 1995 on Small Business.

Although BMT has not been clearly regulated by the state, but the movement of BMT establishing in Indonesian society is widespread. Muslims do not seem too concerned about the legality, for them to strengthen the economy of poor society is a prime priority. Consequently, BMTs in Indonesia are not part of the formal financial sector. They may or may not be registered with the Ministry of Cooperatives; accordingly, they may be placed into either the semiformal or the informal financial sector. As they are not formally regulated, the distinction is of limited relevance. Initiated by a group of Muslim intellectuals and promoted by PINBUK, they are generally referred as BMT.

Seibel states that according to Bank Indonesia, only about 500 of the 3,000 BMT are registered as KSP (Koperasi Simpan Pinjam/Saving and Loan Cooperatives) with the Ministry of Cooperative $(\mathrm{MoC})$. All others are regarded as "pre-cooperatives". With reference to the draft of Micro Finance Institution (MFI) law of 2001, BMT are considered by PINBUK as sharia MFIs (Lembaga Keuangan Mikro Syariah, LKM-S), which may be considered as semiformal institutions: recognized but not regulated. Consequently, there are no auditing requirements; there is no effective supervision and no enforcement of any norms; and to our knowledge no official closing of non-functioning cooperatives (Hans Dieter Seibel, 2005).

\section{CONCLUSION}

From the describing above, we can conclude that the changing of New Order government to accomodate Muslims influence them to establish BMT. In addition, the Chinese dominance in the economics field, on the one side, and the poverty of Muslims, on the other side, become a strong background on why Indonesian Muslims intend to establish an Islamic finance institution. The establishment of BMT by Muslim activists can fill a gap left by the Islamic bank, which have largely neglected the needs of the working poor.

What is remarkable about BMT's is that their development has been supported largely by individuals and private organisastions rather than the government. Interestingly, they did not care about BMT legalisation status or government support. Their goals to strengthen Muslims economy, alleviate the poverty and sava them from usurer (lintah darat) motivated Muslims society to establish BMT. Using Melluci's perspective, the establishing and developing of BMT then can be 
categorized as an instrumental movement to achieve its goals. However, the inisiator and management of BMT should maintain and develop some great programs to alleviate poverty and to strengthen the small enterpreneur or poor people.

To maintain its movement, BMT most urgently need a system of prudential regulation, mandatory auditing and effective supervision by an appropriate financial authority (perhaps delegated to an autonomous auditing federation, but definitely not in the hands of a ministry). Thus, the government should take a role to support and strengthen BMT. In other hand, the associations of BMT, such as PINBUK, may be strengthened to eventually replace a governmental agency like the Ministry of Cooperatives, which, in the framework of massive government interference under the previous political system, seems to have had a more detrimental than constructive effect in terms of building self-reliant, healthy cooperatives. 


\section{Reference}

Abdullah Saeed, Riba. (1996). Interest and Islamic Banking: A Study of the Prohibition of Riba and its Contemporary Interpretation. Leiden: EJ. Brill,

Alberto Melucci. (1996). Challenging Codes: Collectives Action in the Information Age. New York: Cambridge.

Angelo M. Venardo. (2006). Islamic Banking \& Finance in South-East Asia: Its Development \& Future. Singapore: World Scientific Publishing Co. Pte. Ltd.

Bachtiar Effendi. (2003). Islam and the State in Indonesia. Singapore: ISEAS.

Darul Aqsha, et.al,. (1995). Islam in Indonesia: A Survey of Events and Development From 1988 to March 1993. Jakarta: INIS

Dawam Rahardjo. (2002). "Bank Islam" in Ensiklopedi Islam Tematik. Jakarta: PT Ichtiar Baru Van Houve.

Ibid

Jeffrey D. Sachs, (New York: Penguin Press, 2005). The End of Poverty: Economic Possibilities for Our Time. 59-60.

Lesmana, Tedy. (2008). The Role of Islamic Microfinance Cooperatives (Baitul Maal wat Tamwil) in Local Development: Case Study of Three Provinces in Indonesia. Journal of Islamic Economic, 02(1).

M. Amin Aziz. (2007). Kegigihan Sang Perintis. Jakarta: MAA Institute.

M. Amin Aziz. (2008). Tata Cara Pendirian BMT. Jakarta: PKES Publishing.

Minako Sakai. (2008), "Community Development through Islamic Micro-finance: Serving the Financial Needs of the Poor in a Viable Way", in Greg Fealy and Sally White (eds), Expressing Islam: Religious Life and Politics in Indonesia. ISEAS: Singapore.

Muhammad Adnan, et all. (2003). Study on Factors Influencing performance of the Best Baitul Maal wat Tamwils (BMTs) in Indonesia. IQTISAD Journal of Islamic Economics, 04(1).

Muhammad, Djibril. (08 September, 2012). Citing Internet sources URL http://www.republika.co.id/berita/breaking-news/ekonomi/10/12/10/151291-2011-bmtdiperkirakan-tumbuh-45-,.

Muhammad Syafii Antonio. (2008). "Islamic Micro-finance Initiatives to Enhance Small and Medium-seized Enterprises", in Greg Fealy and Sally White (eds), Expressing Islam: Religious Life and Politics in Indonesia. ISEAS, Singapore.

Nur Kholis. (2009). The Contribution of Islamic Microfinance Institution in Increasing Social Welfare in Indonesia. Paper was presented in The 9th Annual Conference on Islamic Studies (ACIS), 2-9 November 2009 in Surakarta. 
Raharjo, Budi. (08 September, 2012). Citing Internet sources URL http://www.republika.co.id/berita/bisnis-syariah/berita/10/07/13/124332-baitul-maal-wattamwil-mulai-interkoneksi.

Robert, W. Hefner. (2003). "Islamizing Capitalism: On the Founding of Indonesia's First Islamic Bank" in Arskal Amin and Azyumardi Azra (eds.) Shari and Politics in Modern Indonesia. Singapore: ISEAS.

Thomas B. Pepinsky. (8 September, 2012). Islamic Finance in Multicultural Indonesia. Citing Internet sources URL https://courses.cit.cornell.edu/tp253/docs/islamic_banking.pdf.

Robert, W. Hefner. (2003). "Islamizing Capitalism: On the Founding of Indonesia's First Islamic Bank" in Arskal Amin and Azyumardi Azra (eds.) Shari and Politics in Modern Indonesia. Singapore: ISEAS.

Robert, W. Hefner. (2000). Islam Pasar Keadilan: Artikulasi Lokal, Kapitalisme dan Demokrasi . Yogyakarta: LkiS.

Richard Robison. (1986). Indonesia: The Rise of Capital. Sydney: Allen \& Unwin.

Robert, W. Hefner. (2000). Civil Islam: Muslim and Democratization in Indonesia. Princeton NJ: Princeton University Press.

James B. Hoesterey. (2008). "Marketing Morality: The Rise, Fall and Rebranding of Aa Gym" in Greg Fealy and Sally White (eds), Expressing Islam: Religious Life and Politics in Indonesia.Singapore: ISEAS.

Nur Kholis, Arif. (02 May 2011). Citing Internet sources URL http://pdm1912.wordpress.com/2010/02/10/kisah-sukses-pemberdayaan-ekonomi-alamuhammadiyah-pekalongan/, accessed on May 02, 2011.

http://pusatbtm.wordpress.com/2010/02/11/pemberdayaan-masyarakat-berbasis-ranting-danmasjid/, accessed on May 02, 2011.

http://www.kopontrendt.com/divisiusaha/detail/1, accessed on June 10, 2012. 